\title{
THE EFFECTS OF CHIA (Salvia hispanica L.) AND QUINOA FLOURS ON THE QUALITY OF RICE FLOUR AND STARCH BASED-CAKES
}

\author{
Kübra Aktaş ${ }^{1}$. Hacer Levent ${ }^{2 *}$ \\ ${ }^{1}$ Food Engineering Department, Faculty of Engineering and Natural Sciences, Gümüşhane University, \\ Gümüşhane, Turkey \\ ${ }^{2}$ Department of Nutrition and Dietetics, Health Sciences Faculty, Karamanoğlu Mehmetbey \\ University, Karaman, Turkey
}

Received / Geliş: 28.03.2018; Accepted / Kabul: 13.06.2018; Published online / Online bask1: 16.07.2018

Aktaş, K., Levent, H. (2018). The effects of chia (Salvia hispanica L.) and quinoa flours on the quality of rice flour and starch based-cakes. GIDA (2018) 43 (4): 644-654 doi: 10.15237/gida.GD18042

\begin{abstract}
The rice flour and corn starch mixture used in the gluten-free cake formulation was replaced with chia flour (CF) and quinoa flour (QF) up to 25\% CF and 25\% QF level. The effects of CF and QF on the physical, chemical and sensory properties of gluten-free cakes were investigated. CF and QF replacement increased the ash, protein, fat, total phenolic content and antioxidant capacity of gluten-free cakes by 1.5, 1.8, 1.3, 3.5 and 2.9 times, respectively, when compared to the control samples. Statistically significant increases were found in $\mathrm{Ca}, \mathrm{P}, \mathrm{K}, \mathrm{Mg}, \mathrm{Fe}$ and $\mathrm{Zn}$ contents of cake samples $(P<0.05)$. The cakes containing $\mathrm{CF}$ and $\mathrm{QF}$, received higher texture and taste-odour scores than control. According to the sensory analyses results it can be concluded that QF and CF can be used in gluten-free cakes up to $20 \%$ and $20 \%$ levels, respectively.

Keywords: Chia, quinoa, gluten-free cake, cake quality.

\section{CHIA (Salvia hispanica L.) VE KİNOA UNLARININ PİRİNÇ UNU VE Nİ̧̧ASTA BAZLI KEKLERİN KALİTESİ ÜZERİNE ETKİLERİ}

\section{ÖZ}

Glutensiz kek formülasyonunda kullanılan pirinç unu ve mısır nişastası karışımı, \%25 chia unu (CF) ve \%25 kinoa unu (QF) oranına kadar CF ve QF ile yer değiştirilmiştir. Glutensiz keklerin fiziksel, kimyasal ve duyusal özelliklerine CF ve QF'nin etkisi araştırılmışıı. CF ve QF'nin kullanımı, kontrol örnekleri ile karşılaştırıldı̆̆ında glutensiz keklerin kül, protein, yağ, toplam fenolik içeriğini ve antioksidan kapasitesini sırasıyla 1.5, 1.8, 1.3, 3.5 ve 2.9 kat artırmıstır. Kek örneklerinin Ca, P, K, $\mathrm{Mg}, \mathrm{Fe}$ ve $\mathrm{Zn}$ içeriklerinde istatistiksel olarak önemli artışlar belirlenmiştir $(P<0.05)$. CF ve QF içeren kekler, kontrolden daha yüksek tekstür ve tat-koku puanı almıştır. Duyusal analiz sonuçlarına göre QF ve CF’nin sırasıyla \%20 ve \%20 oranına kadar glutensiz keklerde kullanılabileceği sonuçuna varılmıştır.

Anahtar kelimeler: Chia, kinoa, glutensiz kek, kek kalitesi

* Corresponding author / Yazışmalardan sorumlu yazar;

$\triangle$ hacerlevent@hotmail.com,

(2)(+90) $3382262000 / 4330$

县(+90) 3382262134 


\section{INTRODUCTION}

Celiac disease (CD) is a chronic inflammatory disorder of the small intestine caused by a permanent intolerance to gluten proteins found in cereal grains such as wheat, barley and rye in genetically susceptible individuals (Murray et al., 2003; Saturni et al., 2010). Clinical and histological improvement was achieved in celiac patients with gluten-free diet but lifelong adherence of CD patients to gluten-free diet is very difficult because products found in modern diets usually contain gluten (Green et al., 2005; Caruso et al., 2013). Moreover, many gluten-free products are poorer in nutrients than that of wheat-based foods intended to replace. CD affects approximately $1 \%$ of the population worldwide and there has been growing number of people diagnosed with $\mathrm{CD}$ by improved analytical methods. CD can occur at any age and it is necessary to produce high quality gluten-free products as an alternative to people who traditionally consume wheat-based products (Saturni et al., 2010; Caruso et al., 2013; Marti and Pagani, 2013; Steffolani et al., 2014).

Quinoa, a pseudocereal that belongs to the Chenopodiaceae family (Jancurová et al., 2009), has a higher nutritive value than traditional cereals (Vega-Gálvez et al., 2010). It has high protein content (10-18\%) with balanced amino acid composition, supplying high contents of lysine and methionine (Coulter and Lorenz, 1990; Nowak et al., 2016). The fat content of raw quinoa seeds was $9.7 \%$ (dry-weight basis) and it has similar fatty acid composition with soybean oils with high amounts of essential fatty acids linoleic $(52.3 \%)$ and linolenic acids (3.9\%) (Coulter and Lorenz, 1990; Ruales and Nair, 1993; Jancurová et al., 2009). These essential fatty acids required for good health, cannot be synthesized in human body and must be obtained from the diet (Costantini et al., 2014). It contains a significant amount of fibre $(2.1-4.9 \%)$, more calcium, magnesium, potassium, iron, copper, riboflavin (B2), $\alpha$-Tocopherol (vitamin E), $\beta$-Carotene and ascorbic acid (vitamin $\mathrm{C}$ ) than wheat, barley and rice (Coulter and Lorenz, 1990; Kozioł, 1992; Jancurová et al., 2009). It is also a rich source of other bioactive compounds (polyphenols, phytosterols, etc.) (Alverez-Jubete et al., 2010).
Furthermore, quinoa does not contain gluten and can be used safely in the production of foods for CD patients (Pagano, 2006).

The Salvia bispanica L, an oilseed plant, is commonly known as chia and is native from southern Mexico and northern Guetamala. It is a traditional food in Central and South America (Coates and Ayerza, 1996; Ixtania et al., 2008; Norlaily et al., 2012). Chia seed contains 25 to $40 \%$ oil with high essential fatty acids (omega) $\omega-3$ alpha-linolenic acid (60\%) and (omega) $\omega-6$ linoleic acid $(20 \%)$. It is also high in protein (19$23 \%$ ), dietary fibre $(18-30 \%)$, vitamins, minerals and antioxidants (Taga et al., 1984; Ixtania et al., 2008; Norlaily et al., 2012). Due to its unique nutritional composition, especially its high unsaturated fatty acid composition, dietary fibre and antioxidant activities its consumption helps to increase satiety index and decreases the risk of various types of diseases such as cardiovascular diseases, cancer, diabetes, inflammatory and autoimmune diseases (Simopoulos, 2002; Muñoz et al., 2013).

The aim of this study was to formulate gluten-free cake prepared from quinoa and chia flour to increase the nutritional value of gluten-free cakes and to ensure that $\mathrm{CD}$ patients have adequate amounts of nutrients.

\section{MATERIALS AND METHODS Materials}

Chia seeds, whole quinoa flour, rice flour, corn starch, fine granulating sucrose, all purpose shortening, skimmed milk powder, whole egg, salt, baking powder and ethyl vanillin were obtained from local markets in Konya. Chia flour (CF) was obtained by milling of chia seeds with coffee grinder (Tefal, Istanbul, Turkey). Xanthan gum (Vatan Gida, Istanbul, Turkey) and diacetyl tartaric acid esters of mono and diglycerides (DATEM; Rikevita, Malaysia) were used in cake formulations.

\section{Methods}

\section{Cake preparation}

Control gluten-free cake sample was prepared using the following recipe: Gluten free flour 
mixture (50 g rice flour: $50 \mathrm{~g}$ corn starch), fine granulating sucrose (75 g), shortening (75 g), whole egg (75 g), skimmed milk powder (5 g), salt $(0.5 \mathrm{~g})$, baking powder $(4.5 \mathrm{~g})$, xanthan gum $(1 \mathrm{~g})$, DATEM (0.5 g), ethyl vanillin $(0.1 \mathrm{~g})$. In CF and quinoa flour (QF) enriched cake samples, glutenfree flour mixture was replaced with 5\% CF: $5 \%$ QF, 10\% CF:10\% QF, 15\% CF:15\% QF, 20\% CF:20\% QF and 25\% CF: 25\% QF (w/w), respectively. All purpose shortening and fine granulating sucrose were whipped to a white cream in a Hobart mixer (Hobart N50, Canada Inc., North York, Ontario, Canada). Then eggs were added and whipped for 5 minutes then the other ingredients were added and the batter was mixed for additional 1 minute. One hundred and thirty grams of cake batter was placed into baking pans with $7.5 \times 6.6 \times 12 \mathrm{~cm}$ dimensions and baked at $175{ }^{\circ} \mathrm{C}$ for $35 \mathrm{~min}$ in the oven (Bosch HBT 112, Athens, Greece). After baking, cakes were removed from the pan and left for 30 minutes to cool. Cooled cakes were packed in polyethylene bags and sealed at room temperature $\left(22{ }^{\circ} \mathrm{C}\right)$ until their test and analyses.

\section{Chemical properties}

The cake samples were analysed for moisture (AACC Method 44-01), ash (AACC Method 0801), protein (AACC Method 46-12) and fat (AACC Method 30-25) content according to AACC (1990). Mineral element contents of the samples were determined by inductively-coupled plasma spectroscopy, ICP-AES (Vista series, Varian International AG, Switzerland). Dry samples were digested using closed vessel microwave digestion oven (MARS 5, CEM Corporation, USA) with concentrated nitric acid and sulphuric acid. Mineral concentrations were determined by ICP-AES (Bubert and Hagenah, 1987).

Phytic acid (PA) was measured by a colorimetric method according to Haug and Lantzsch (1983). PA in the sample was extracted using a solution of $\mathrm{HCl}(0.2 \mathrm{~mol} / \mathrm{L})$ and precipitated by solution of ammonium iron (III) sulphate dodecahydrate. For determining PA, phytate phosphorus value was multiplied by a factor 3.546.
The extracts for the measurement of total phenolic content (TPC) and antioxidant capacity were prepared according to modified methods of Wronkowska et al. (2010). The $1 \mathrm{~g}$ of freshly ground samples were extracted with $10 \mathrm{~mL}$ of $80 \%$ aqueous methanol by shaking for 2 hours at $37^{\circ}$ C. Then samples centrifuged at $2600 \mathrm{~g}$ for 15 minutes. The fresh methanolic extracts were used to determine the TPC and their ability to scavenge DPPH (2,2- diphenyl-1-picrylhydrazyl) radicals.

The TPC of the methanolic extracts was determined by using Folin-Ciocalteu reagent as described by Wronkowska et al. (2010) with some modifications. Briefly, $0.1 \mathrm{~mL}$ aliquot extract was mixed with $0.9 \mathrm{~mL}$ of de-ionized water, $2 \mathrm{~mL}$ of sodium carbonate $(10 \% \mathrm{w} / \mathrm{v})$ and $1 \mathrm{~mL}$ of FolinCiocalteu reagent $(90 \% \mathrm{v} / \mathrm{v})$. The mixture was incubated in the dark for 1 hour at room temperature. The absorbance was then measured at $765 \mathrm{~nm}$ by using a spectrophotometer (Mecasys Optizen Pop UV-Vis Single Beams Spectrophotometer, 10F, 640-3, Banseok-dong, Yuseong-gu, Daejeon, Korea). The results are expressed in $\mu \mathrm{g}$ of gallic acid equivalent (GAE) per g dry weight basis.

The free radical scavenging capacity of the sample extracts was measured using a stable 2,2 diphenyl1-picrylhydrazyl (DPPH) radical according to the method given also by Wronkowska et al., (2010) with some modifications. The extract $(100 \mu \mathrm{L})$ was mixed with freshly made methanolic DPPH solution $(250 \mu \mathrm{l}, 10 \mathrm{mg} \mathrm{DPPH} / 25 \mathrm{~mL} 80 \%$ methanol) and $80 \%$ methanol $(2 \mathrm{~mL})$. The mixture was left in the dark for 20 minutes at room temperature. The absorbance was then measured at $517 \mathrm{~nm}$ against the blank. The blank consisted of $80 \%$ methanol and the reagent solution without $80 \%$ methanolic extract added and the procedure was performed as described above. Antioxidant capacity was calculated as percentage of discolouration defined as in "Eq. $1 "$. 


\section{Physical measurements}

Volume index, symmetry index and uniformity index of the cakes were measured by using AACC template method 10-91 (AACC, 1990). Color measurements were made on the cake's crust and crumb by measuring $L^{*}$ (light /dark), a (red/green), and $\mathrm{b}^{*}$ (yellow/blue) parameters with a chromo meter (Model CR 400, Minolta Camera, Co. Ltd., Osaka, Japan). The chroma (C*) $\left(\sqrt{ }\left(a^{* 2}+b^{* 2}\right)\right)$ describes the brightness or vividness of color. Hue angle $(\mathrm{H})$, which indicates the tone (0: reddish tones; $\sim 90=$ yellowish tones), was calculated as $\arctan \left[b^{*} / a^{*}\right]$ (if $a>0$ and $b>0$ ) or $\arctan \left[b^{*} / a^{*}\right]+180^{\circ}$ (if $a<0$ and $b>0$ ) (Francis, 1998; Gómez et al., 2008).

Specific gravity of the cake batter was calculated by dividing of the weight of a certain volume of cake batter to the weight of the same volume of distilled water (Gómez et al., 2008).

\section{Sensory properties}

Cakes were evaluated by untrained panellists $(n=26)$ on the basis of acceptance of appearance, texture, taste-odour, mouthfeel and overall acceptability on a nine-point hedonic scale where 1- dislike extremely, 2- dislike very much, 3dislike moderately, 4- dislike slightly, 5- neither like nor dislike, 6- like slightly, 7- like moderately, 8- like very much, 9- like extremely.

\section{Statistical analysis}

The data were analysed by using statistical software JMP 8.0 (SAS Institute, Cary, NC, USA). The values are average of triplicate determinations on two replicate cake preparations. Tukey HSD was used to determine significant differences between the treatments. Significant differences were based on a $P<0.05$.

\section{RESULTS AND DISCUSSION}

\section{Analytical results}

$\mathrm{CF}$ and QF used to prepare gluten-free cakes contain $4.21 \%$ and $3.47 \%$ ash, $19.56 \%$ and $12.36 \%$ protein, $31.87 \%$ and $5.65 \%$ fat, 2165.48 $\mathrm{mg} / 100 \mathrm{~g}$ and $1640.89 \mathrm{mg} / 100 \mathrm{~g} \mathrm{PA}, 610.68$ $\mathrm{mg} / 100 \mathrm{~g}$ and $462.74 \mathrm{mg} / 100 \mathrm{~g}$ phytate phosphorus, $1628.45 \mu \mathrm{g} / \mathrm{g}$ and $1260.14 \mu \mathrm{g} / \mathrm{g}$ TPC and $88.45 \%$ and $59.95 \%$ antioxidant capacity in dry weight basis, respectively. The $\mathrm{Ca}, \mathrm{P}, \mathrm{K}, \mathrm{Mg}$,
Fe and $\mathrm{Zn}$ contents of $\mathrm{CF}$ and QF were 612.31 $\mathrm{mg} / 100 \mathrm{~g}, 987.52 \mathrm{mg} / 100 \mathrm{~g}, 748.65 \mathrm{mg} / 100 \mathrm{~g}$, $332.14 \mathrm{mg} / 100 \mathrm{~g}, 7.21 \mathrm{mg} / 100 \mathrm{~g}, 4.38 \mathrm{mg} / 100 \mathrm{~g}$ (CF) and $42.10 \mathrm{mg} / 100 \mathrm{~g}, 369.94 \mathrm{mg} / 100 \mathrm{~g}$, $803.77 \mathrm{mg} / 100 \mathrm{~g}, 182.99 \mathrm{mg} / 100 \mathrm{~g}, 7.51 \mathrm{mg} / 100 \mathrm{~g}$ and $2.25 \mathrm{mg} / 100 \mathrm{~g}(\mathrm{QF})$, respectively. $\mathrm{L}^{*}, \mathrm{a}^{*}, \mathrm{~b}^{*}$, $\mathrm{C}^{*}$ and hue values were $42.14,2.39,8.42,8.75$ and 74.15 for CF; 87.08, -0.29, 11.61, 11.61 and 91.43 for QF, respectively. Similar results have been reported in previous works (Bilgiçli and Ibanoğlu, 2015; Muñoz et al., 2013; Pizarro et al., 2013; Ranhotra et al., 1993).

\section{Chemical properties}

Proximate composition, phytic acid, phytate phosphorus, total phenolic contents and antioxidant capacity of gluten-free cakes are given in Table 1 and Table 2. The moisture contents of gluten-free cakes containing $\mathrm{CF}$ and $\mathrm{QF}$ were found higher than that of control prepared with rice flour and corn starch. This may be caused by the mucilage which is known to have excellent water holding properties found in chia fibre. It was reported that chia has possible applications in bakery products requiring hydration and conservation of freshness (Vázquez- Ovando et al., 2009). Increasing amount of $\mathrm{CF}$ and $\mathrm{QF}$ increased the ash, protein, fat, TPC and antioxidant capacity of the cake samples significantly $(P<0.05)$. These increases were 1.5 times in ash, 1.8 times in protein, 1.3 times in fat, 3.5 times in TPC and 2.9 times in antioxidant capacity. The rich composition of $\mathrm{CF}$ and $\mathrm{QF}$ affected the chemical composition of the final product. Similarly, Barrientos et al. (2012) prepared sugar-snap cookies by replacing wheat flour with CF at $10 \%$ and $20 \%$ (flour basis) and reported that cookies supplemented with $\mathrm{CF}$ contained more ash, protein, fat, crude fibre, calcium and zinc than control cookies. Alencar et al. (2015) studied the effects of whole quinoa and amaranth flour (20\%, flour and starch basis) with sweeteners on gluten-free bread quality and reported that the bread containing amaranth, quinoa and sweeteners showed higher protein, lipid and ash content than that of control bread. 
Table 1. Proximate composition of gluten-free cakes

\begin{tabular}{lcccc}
\hline & Moisture (\%) & Ash $(\%)^{*}$ & Protein $(\%)^{*}$ & Fat $(\%)^{*}$ \\
\hline Control & $25.77 \pm 0.08^{\mathrm{e}}$ & $1.58 \pm 0.03^{\mathrm{f}}$ & $5.46 \pm 0.08^{\mathrm{f}}$ & $25.42 \pm 0.10^{\mathrm{f}}$ \\
$5 \%$ CF-5\% QF & $27.37 \pm 0.06^{\mathrm{b}}$ & $1.72 \pm 0.04^{\mathrm{e}}$ & $6.40 \pm 0.14^{\mathrm{e}}$ & $26.93 \pm 0.07^{\mathrm{e}}$ \\
$10 \%$ CF-10\% QF & $26.01 \pm 0.04^{\mathrm{d}}$ & $1.83 \pm 0.01^{\mathrm{d}}$ & $7.11 \pm 0.16^{\mathrm{d}}$ & $28.23 \pm 0.16^{\mathrm{d}}$ \\
$15 \% \mathrm{CF}-15 \%$ QF & $27.17 \pm 0.07^{\mathrm{c}}$ & $2.01 \pm 0.03^{\mathrm{c}}$ & $7.92 \pm 0.17 \mathrm{c}$ & $29.87 \pm 0.14 \mathrm{c}$ \\
$20 \% \mathrm{CF}-20 \%$ QF & $28.33 \pm 0.03^{\mathrm{a}}$ & $2.16 \pm 0.04^{\mathrm{b}}$ & $8.83 \pm 0.10^{\mathrm{b}}$ & $31.42 \pm 0.06^{\mathrm{b}}$ \\
$25 \%$ CF-25\% QF & $28.40 \pm 0.07^{\mathrm{a}}$ & $2.35 \pm 0.01^{\mathrm{a}}$ & $9.61 \pm 0.16^{\mathrm{a}}$ & $32.82 \pm 0.10^{\mathrm{a}}$ \\
\hline
\end{tabular}

Values are the average of triplicate measurements on the duplicate sample \pm standard deviation;

* Results are dry-weight basis; CF, Chia flour; QF, Quinoa flour; Data in the same column sharing a lowercase common letter are not significantly $(P<0.05)$ different.

Table 2. Phytic acid, phytate phosphorus, total phenolic contents and antioxidant capacity of glutenfree cakes

\begin{tabular}{lcccc}
\hline & $\begin{array}{c}\text { Phytic acid } \\
(\mathrm{mg} / 100 \mathrm{~g})\end{array}$ & $\begin{array}{c}\text { Phytate } \\
\text { phosphorus } \\
(\mathrm{mg} / 100 \mathrm{~g})\end{array}$ & $\begin{array}{c}\text { Total phenolic } \\
\text { content }(\mu \mathrm{g} / \mathrm{g})^{*}\end{array}$ & $\begin{array}{c}\text { Antioxidant } \\
\text { capacity }(\%)^{*}\end{array}$ \\
\hline Control & $133.59 \pm 2.40^{\mathrm{f}}$ & $37.67 \pm 2.88^{\mathrm{f}}$ & $151.11 \pm 4.23^{\mathrm{f}}$ & $16.43 \pm 0.35^{\mathrm{f}}$ \\
$5 \% \mathrm{CF}-5 \%$ QF & $272.99 \pm 2.29^{\mathrm{e}}$ & $76.99 \pm 2.61^{\mathrm{e}}$ & $218.74 \pm 2.83^{\mathrm{e}}$ & $27.03 \pm 0.23^{\mathrm{e}}$ \\
$10 \% \mathrm{CF}-10 \%$ QF & $435.70 \pm 2.12^{\mathrm{d}}$ & $122.87 \pm 1.22^{\mathrm{d}}$ & $301.33 \pm 3.49^{\mathrm{d}}$ & $34.92 \pm 0.52^{\mathrm{d}}$ \\
$15 \% \mathrm{CF}-15 \%$ QF & $583.61 \pm 2.62^{\mathrm{c}}$ & $164.58 \pm 2.32^{\mathrm{c}}$ & $345.56 \pm 5.60^{\mathrm{c}}$ & $40.98 \pm 0.47 \mathrm{c}$ \\
$20 \% \mathrm{CF}-20 \%$ QF & $736.58 \pm 2.14^{\mathrm{b}}$ & $207.72 \pm 2.79^{\mathrm{b}}$ & $433.21 \pm 2.74^{\mathrm{b}}$ & $43.99 \pm 0.38^{\mathrm{b}}$ \\
$25 \% \mathrm{CF}-25 \%$ QF & $878.75 \pm 2.18^{\mathrm{a}}$ & $247.81 \pm 1.84^{\mathrm{a}}$ & $525.19 \pm 5.84^{\mathrm{a}}$ & $48.14 \pm 0.17^{\mathrm{a}}$ \\
\hline
\end{tabular}

Values are the average of triplicate measurements on the duplicate sample \pm standard deviation;

* Results are dry-weight basis; CF, Chia flour; QF, Quinoa flour; Data in the same column sharing a lowercase common letter are not significantly $(P<0.05)$ different.

Repo-Carrasco-Valencia and Serna (2011) reported that quinoa can be considered as a good source of polyphenol and other antioxidant compounds. Costantini et al. (2014) reported that the use of chia flour (at 10\% level) led to a significant increase in the TPC and antioxidant capacity of bread samples. The PA and phytate phosphorus content of cake samples were ranged from $133.59 \mathrm{mg} / 100 \mathrm{~g}$ to $878.75 \mathrm{mg} / 100 \mathrm{~g}$ and $37.67 \mathrm{mg} / 100 \mathrm{~g}$ to $247.81 \mathrm{mg} / 100 \mathrm{~g}$, respectively. As expected, the use of CF and QF caused substantial increase in the levels of PA and phytate phosphorus content of gluten-free cakes. Phytic acid is considered to be an antinutrient due to its ability to bind minerals, proteins and starch either indirectly or directly. This binding alters the bioavailability or digestibility of these nutrients (Zhou and Erdman, 1995; Rickard and Thompson, 1997; Oatway et al. 2001; Kumar et al. 2010). However, some healhtful effects of phytic acid including antioxidant and anticarcinogenic effects have been reported by many researchers (Graf and Eaton, 1993;
Thompson 1993; Zhou and Erdman, 1995; Febles et al. 2002). But, dosage information is limited for humans to elicit beneficial effects (Kumar et al. 2010).

\section{Mineral contents}

Mineral contents of gluten-free cakes are given in Table 3. In general, all the mineral content of gluten-free cakes increased significantly $(P<0.05)$ by the addition of $\mathrm{CF}$ and $\mathrm{QF}$, and the richest mineral composition was obtained at highest enrichment ratio. The $\mathrm{Ca}, \mathrm{P}, \mathrm{K}, \mathrm{Mg}, \mathrm{Fe}$ and $\mathrm{Zn}$ contents of gluten-free cakes containing $25 \% \mathrm{CF}$ and $25 \%$ QF were found to be 7.2, 2.4, 3.1, 10.3, 4.4 and 3.0 times higher than the control. The Recommended Dietary Allowances (RDAs) for adults are $900 \mathrm{mg}$ of calcium, 1.4-1.5 g phosphorus, $2 \mathrm{~g}$ of potassium, $350 \mathrm{mg}$ of magnesium, $10 \mathrm{mg}$ of iron and $13 \mathrm{mg}$ of zinc (Demirci, 2011). 
Table 3. Mineral contents of gluten-free cakes ( $\mathrm{mg} / 100 \mathrm{~g})^{*}$

\begin{tabular}{lcccccc}
\hline & $\mathrm{Ca}$ & $\mathrm{P}$ & $\mathrm{K}$ & $\mathrm{Mg}$ & $\mathrm{Fe}$ & $\mathrm{Zn}$ \\
\hline Control & $21.06 \pm 0.25^{\mathrm{f}}$ & $178.51 \pm 0.57^{\mathrm{f}}$ & $127.75 \pm 0.42^{\mathrm{f}}$ & $6.91 \pm 0.14^{\mathrm{f}}$ & $0.56 \pm 0.03^{\mathrm{f}}$ & $0.49 \pm 0.03^{\mathrm{f}}$ \\
$5 \%$ CF-5\% QF & $48.33 \pm 0.17^{\mathrm{e}}$ & $224.67 \pm 0.85^{\mathrm{e}}$ & $185.93 \pm 0.68^{\mathrm{e}}$ & $18.23 \pm 0.31^{\mathrm{e}}$ & $0.93 \pm 0.01^{\mathrm{e}}$ & $0.66 \pm 0.01^{\mathrm{e}}$ \\
$10 \%$ CF-10\% QF & $69.42 \pm 0.20^{\mathrm{d}}$ & $277.38 \pm 0.37^{\mathrm{d}}$ & $236.32 \pm 0.35^{\mathrm{d}}$ & $33.09 \pm 0.45^{\mathrm{d}}$ & $1.22 \pm 0.06^{\mathrm{d}}$ & $0.87 \pm 0.04^{\mathrm{d}}$ \\
$15 \%$ CF-15\% QF & $94.76 \pm 0.28^{\mathrm{c}}$ & $326.60 \pm 0.61^{\mathrm{c}}$ & $280.61 \pm 0.71^{\mathrm{c}}$ & $42.10 \pm 0.27^{\mathrm{c}}$ & $1.65 \pm 0.01^{\mathrm{c}}$ & $1.06 \pm 0.03^{\mathrm{c}}$ \\
$20 \%$ CF-20\% QF & $125.18 \pm 0.14^{\mathrm{b}}$ & $381.36 \pm 0.44^{\mathrm{b}}$ & $343.18 \pm 0.54^{\mathrm{b}}$ & $55.86 \pm 0.18^{\mathrm{b}}$ & $2.11 \pm 0.03^{\mathrm{b}}$ & $1.22 \pm 0.01^{\mathrm{b}}$ \\
$25 \%$ CF-25\% QF & $151.40 \pm 0.21^{\mathrm{a}}$ & $422.18 \pm 0.71^{\mathrm{a}}$ & $394.72 \pm 0.28^{\mathrm{a}}$ & $71.40 \pm 0.59^{\mathrm{a}}$ & $2.46 \pm 0.04^{\mathrm{a}}$ & $1.45 \pm 0.04^{\mathrm{a}}$ \\
\hline
\end{tabular}

*Results are dry-weight basis; Values are the average of triplicate measurements on the duplicate sample \pm standard deviation; CF, Chia flour; QF, Quinoa flour; Data in the same column sharing a lowercase common letter are not significantly $(P<0.05)$ different.

Gluten-free cake (100 g, dry weight) containing $25 \% \quad \mathrm{CF}$ and $25 \%$ QF meets the daily requirements of $\mathrm{Ca}, \mathrm{P}, \mathrm{K}, \mathrm{Mg}, \mathrm{Fe}$ and $\mathrm{Zn}$ for adults by $16.8 \%, 29.1 \%, 19.7 \%, 20.4 \%, 24.6 \%$ and $11.2 \%$ respectively. These RDA ratios were $2.3 \%$ of $\mathrm{Ca}, 12.3 \%$ of $\mathrm{P}, 6.4 \%$ of $\mathrm{K}, 2.0 \%$ of $\mathrm{Mg}$, $5.6 \%$ of $\mathrm{Fe}$ and $3.8 \%$ of $\mathrm{Zn}$ in the control glutenfree cake.

The rich mineral contents of CF and QF affected the mineral content of the final product. It is reported that quinoa is also an excellent source of $\mathrm{Fe}, \mathrm{Ca}, \mathrm{Mg}, \mathrm{B}$ vitamins and fibre (Pagano, 2006). Gohara et al. (2013) used chia and azuki flour in gluten-free chocolate cakes and conclude that the addition of $20 \%$ of both flours introduced higher mineral contents in chocolate cakes. (Levent, 2017) reported that chia seed flour usage in gluten-free noodles caused significant increase in $\mathrm{Ca}, \mathrm{P}, \mathrm{K}, \mathrm{Mg}, \mathrm{Fe}$ and $\mathrm{Zn}$ contents $(P<0.05)$. In the study conducted by Giménez et al. (2016), gluten-free spaghetti-type pasta made with corn flour enriched with 30\% broad bean flour and $20 \%$ quinoa flour and it is reported that the substitution of broad bean and quinoa flour separately increased remarkably the contents of dietary fibre, unsaturated fatty acids, iron and zinc. The mineral enrichment of gluten-free foods is important for celiac patients because iron, folate, vitamin $\mathrm{B} 12$, vitamin $\mathrm{D}$, zinc, and magnesium deficiencies are common in untreated celiac disease and nutrient deficiencies may be responsible for extra intestinal signs/symptoms of celiac disease (Caruso et al., 2013).

\section{Physical properties of cake samples}

Some physical properties of cake batters and cake samples are given in Table 4. The specific gravity values of the gluten-free cake batters were found to be higher than the control samples except for the 5\% CF and 5\% QF replacement level. The volume index is an indicator of cake volume which is strongly influences consumer preference (Gómez et al., 2008). 10\% CF-10\% QF and 15\% CF-15\% QF gave the highest volume index value. All gluten-free cakes containing CF and QF had higher volume index values than control $(P$ $<0.05)$. Borneo et al., (2010) studied the effect of replacing $25 \mathrm{~g} / 100 \mathrm{~g}, 50 \mathrm{~g} / 100$ and $75 \mathrm{~g} / 100 \mathrm{~g}$ of the eggs or the oil in cake formulation by chia gel and reported that substituting egg or oil with chia gel up to $25 \%$ level maintained the functional properties of cake samples. The symmetry index values varied between $-1 \mathrm{~mm}$ and $13 \mathrm{~mm}$ and the lowest symmetry index value was obtained at $20 \%$ CF and 20\% QF level. The high symmetry index value showed that cakes mainly rise in the central part (Borneo et al., 2010). The uniformity index values of gluten-free cakes ranged from $-2 \mathrm{~mm}$ to $3 \mathrm{~mm}$ which are near zero. Uniformity index is desired to be close to zero for good cake quality (Bath et al., 1992).

In the study conducted by Lorenz et al. (1995), quinoa flour was used in bread, cake and cookie formulations at 5,10,20 and 30\% levels and it was reported that cake pore structure became more open and the texture less silky as the level of quinoa substitution increased. In the same study, cake quality was found acceptable at 5\% and $10 \%$ quinoa flour usage levels. 
Table 4. Physical properties of gluten-free cake batter and cake samples

\begin{tabular}{lcccc}
\hline & $\begin{array}{c}\text { Specific gravity } \\
\left(\mathrm{g} / \mathrm{cm}^{3}\right)\end{array}$ & $\begin{array}{c}\text { Volume Index } \\
(\mathrm{mm})\end{array}$ & $\begin{array}{c}\text { Symmetry Index } \\
(\mathrm{mm})\end{array}$ & $\begin{array}{c}\text { Uniformity } \\
\text { Index } \\
(\mathrm{mm})\end{array}$ \\
\hline Control & $1.01 \pm 0.03^{\mathrm{b}}$ & $133 \pm 0.57^{\mathrm{d}}$ & $5 \pm 0.28^{\mathrm{b}}$ & $1 \pm 0.14^{\mathrm{b}}$ \\
$5 \% \mathrm{CF}-5 \% \mathrm{QF}$ & $1.05 \pm 0.01^{\mathrm{ab}}$ & $137 \pm 0.71^{\mathrm{c}}$ & $4 \pm 0.14^{\mathrm{c}}$ & $-2 \pm 0.00^{\mathrm{e}}$ \\
$10 \% \mathrm{CF}-10 \% \mathrm{QF}$ & $1.09 \pm 0.04^{\mathrm{a}}$ & $146 \pm 0.48^{\mathrm{a}}$ & $4 \pm 0.14^{\mathrm{c}}$ & $0 \pm 0.14^{\mathrm{c}}$ \\
$15 \% \mathrm{CF}-15 \% \mathrm{QF}$ & $1.08 \pm 0.01^{\mathrm{a}}$ & $146 \pm 0.85^{\mathrm{a}}$ & $13 \pm 0.00^{\mathrm{a}}$ & $3 \pm 0.42^{\mathrm{a}}$ \\
$20 \% \mathrm{CF}-20 \% \mathrm{QF}$ & $1.10 \pm 0.04^{\mathrm{a}}$ & $142 \pm 0.57^{\mathrm{b}}$ & $-1 \pm 0.14^{\mathrm{d}}$ & $3 \pm 0.00^{\mathrm{a}}$ \\
$25 \% \mathrm{CF}-025 \mathrm{QF}$ & $1.09 \pm 0.02^{\mathrm{a}}$ & $136 \pm 0.71^{\mathrm{c}}$ & $5 \pm 0.28^{\mathrm{b}}$ & $-1 \pm 0.14 \mathrm{~d}$ \\
\hline
\end{tabular}

Values are the average of triplicate measurements on the duplicate sample \pm standard deviation. CF, Chia flour; QF, Quinoa flour; Data in the same column sharing a lowercase common letter are not significantly $(P<0.05)$ different.

\section{Color values of cake crumb and crust}

The color of the cakes is one of the most important characteristics which affect the acceptability of product by consumers. Color values of gluten-free cake samples prepared with $\mathrm{CF}$ and $\mathrm{QF}$ are given in Table 5. In general, as the levels of $\mathrm{CF}$ and $\mathrm{QF}$ increased in the formulation, lightness $\left(\mathrm{L}^{*}\right)$, yellowness $\left(\mathrm{b}^{*}\right)$ and hue values of gluten-free cakes decreased and redness $\left(\mathrm{a}^{*}\right)$ values increased. At the 25\% CF and 25\% QF level, the highest redness $\left(\mathrm{a}^{*}\right)$ and the lowest chroma $\left(\mathrm{C}^{*}\right)$ values were obtained in cake crumb. High chroma values indicate vivid colors whilst low values near 0 indicate subdued colors (Gómez et al., 2008). Similarly, Pizarro et al. (2013) reported that whole chia powder usage $(15 \mathrm{~g} / 100 \mathrm{~g}$ flour mixture) in pound cake formulation contributed to a decrease in $\mathrm{L}^{*}$ (making the crumb darker), $\mathrm{C}^{*}$ (with a less saturated color) and $\mathrm{h}$ values (tending more red) of samples. Demir (2014) studied the effect of quinoa flour on the quality of gluten-free tarhana and observed a decrease in $\mathrm{L}^{*}, \mathrm{~b}^{*}$ and an increase in $\mathrm{a}^{*}$ values of tarhana samples with the addition of quinoa at 40-60\% levels.

Color values of $\mathrm{CF}$ and $\mathrm{QF}$ had a significant effect $(P<0.05)$ on color parameters of the final product. In addition, the rich composition of $\mathrm{CF}$ and QF may accelerate the Maillard reaction which may increase darkness and redness of gluten-free cakes. But the cake crumb does not reach temperatures above $100{ }^{\circ} \mathrm{C}$ and Maillard or caramelization reactions occur on the cake crust rather than cake crumb. Therefore, the color of raw materials and their interactions are effective on cake crumb color (Gómez et al., 2008).

Table 5. Crust and crumb color values of gluten-free cakes

\begin{tabular}{llllll}
\hline CAKE CRUST & L$^{*}$ & $\mathrm{a}^{*}$ & $\mathrm{~b}^{*}$ & $\mathrm{C}^{*}$ & hue \\
\hline Control & $48.91 \pm 0.27^{\mathrm{a}}$ & $3.27 \pm 0.07^{\mathrm{f}}$ & $20.82 \pm 0.12^{\mathrm{a}}$ & $21.08 \pm 0.14^{\mathrm{a}}$ & $81.08 \pm 0.12^{\mathrm{a}}$ \\
$5 \%$ CF-5\% QF & $41.16 \pm 0.30^{\mathrm{b}}$ & $7.99 \pm 0.10^{\mathrm{e}}$ & $15.98 \pm 0.07^{\mathrm{b}}$ & $17.87 \pm 0.11^{\mathrm{c}}$ & $63.43 \pm 0.18^{\mathrm{b}}$ \\
$10 \%$ CF-10\% QF & $37.81 \pm 0.18^{\mathrm{c}}$ & $9.34 \pm 0.04^{\mathrm{d}}$ & $14.98 \pm 0.05^{\mathrm{c}}$ & $17.65 \pm 0.06^{\mathrm{c}}$ & $58.07 \pm 0.03^{\mathrm{c}}$ \\
$15 \%$ CF-15\% QF & $36.88 \pm 0.25^{\mathrm{d}}$ & $10.02 \pm 0.06^{\mathrm{c}}$ & $13.22 \pm 0.04^{\mathrm{e}}$ & $16.58 \pm 0.02^{\mathrm{d}}$ & $52.88 \pm 0.30^{\mathrm{d}}$ \\
$20 \%$ CF-20\% QF & $36.44 \pm 0.23^{\mathrm{d}}$ & $12.84 \pm 0.05^{\mathrm{a}}$ & $14.72 \pm 0.09^{\mathrm{d}}$ & $19.53 \pm 0.10^{\mathrm{b}}$ & $48.89 \pm 0.08^{\mathrm{f}}$ \\
$25 \%$ CF-\% 25 QF & $31.86 \pm 0.17^{\mathrm{e}}$ & $10.84 \pm 0.13^{\mathrm{b}}$ & $12.87 \pm 0.07^{\mathrm{f}}$ & $16.83 \pm 0.14^{\mathrm{d}}$ & $49.88 \pm 0.19^{\mathrm{e}}$ \\
\hline CAKE CRUMB & & & & \\
\hline Control & $62.10 \pm 0.21^{\mathrm{a}}$ & $-2.10 \pm 0.04^{\mathrm{e}}$ & $17.78 \pm 0.08^{\mathrm{a}}$ & $17.90 \pm 0.09^{\mathrm{a}}$ & $96.74 \pm 0.11^{\mathrm{a}}$ \\
$5 \%$ CF-5\% QF & $61.20 \pm 0.14^{\mathrm{b}}$ & $-0.62 \pm 0.03^{\mathrm{d}}$ & $15.19 \pm 0.06^{\mathrm{b}}$ & $15.20 \pm 0.06^{\mathrm{b}}$ & $92.34 \pm 0.11^{\mathrm{b}}$ \\
$10 \%$ CF-10\% QF & $56.16 \pm 0.28^{\mathrm{c}}$ & $0.53 \pm 0.05^{\mathrm{c}}$ & $13.87 \pm 0.03^{\mathrm{c}}$ & $13.88 \pm 0.04^{\mathrm{c}}$ & $87.82 \pm 0.21^{\mathrm{c}}$ \\
$15 \%$ CF-15\% QF & $54.61 \pm 0.16^{\mathrm{d}}$ & $0.77 \pm 0.08^{\mathrm{b}}$ & $13.21 \pm 0.04^{\mathrm{d}}$ & $13.23 \pm 0.06^{\mathrm{d}}$ & $86.65 \pm 0.31^{\mathrm{d}}$ \\
$20 \%$ CF-20\% QF & $49.03 \pm 0.11^{\mathrm{e}}$ & $1.88 \pm 0.01^{\mathrm{a}}$ & $12.04 \pm 0.08^{\mathrm{e}}$ & $12.18 \pm 0.07^{\mathrm{e}}$ & $81.12 \pm 0.11^{\mathrm{e}}$ \\
$25 \%$ CF-\%25 QF & $49.45 \pm 0.09^{\mathrm{e}}$ & $1.89 \pm 0.05^{\mathrm{a}}$ & $11.88 \pm 0.06^{\mathrm{f}}$ & $12.03 \pm 0.04^{\mathrm{f}}$ & $80.98 \pm 0.27 \mathrm{e}$ \\
\hline
\end{tabular}

Values are the average of triplicate measurements on the duplicate sample \pm standard deviation. CF, Chia flour; QF, Quinoa flour; Data in the same column sharing a lowercase common letter are not significantly $(P<0.05)$ different. 


\section{Sensory properties}

Sensory properties of gluten-free cake samples are presented in Figure 1. CF and QF usage improved the taste-odour score of gluten-free cakes compared to control. Cakes with $10 \% \mathrm{CF}$ and $10 \% \mathrm{QF}$ received the highest appearance, texture, mouthfeel and overall acceptability score in all cake samples. Usage of $25 \% \mathrm{CF}$ and $25 \%$ QF decreased especially appearance, mouthfeel and overall acceptability scores of gluten-free cakes. Pizarro et al. (2013) reported that pound cake produced with whole chia powder $(15 \mathrm{~g} / 100$ $\mathrm{g}$ flour mixture) showed good sensory acceptance. In a study by Steffolani et al. (2014), it was found that the use of chia flour at 15\% (rice flour basis) in gluten-free bread formulation did not reduced sensorial acceptability of these products. In the study conducted by Turkut et al. (2016) it was reported that quinoa flour can be successfully used in gluten-free bread formulation and $25 \%$ quinoa bread gained higher sensory scores with its softer texture.

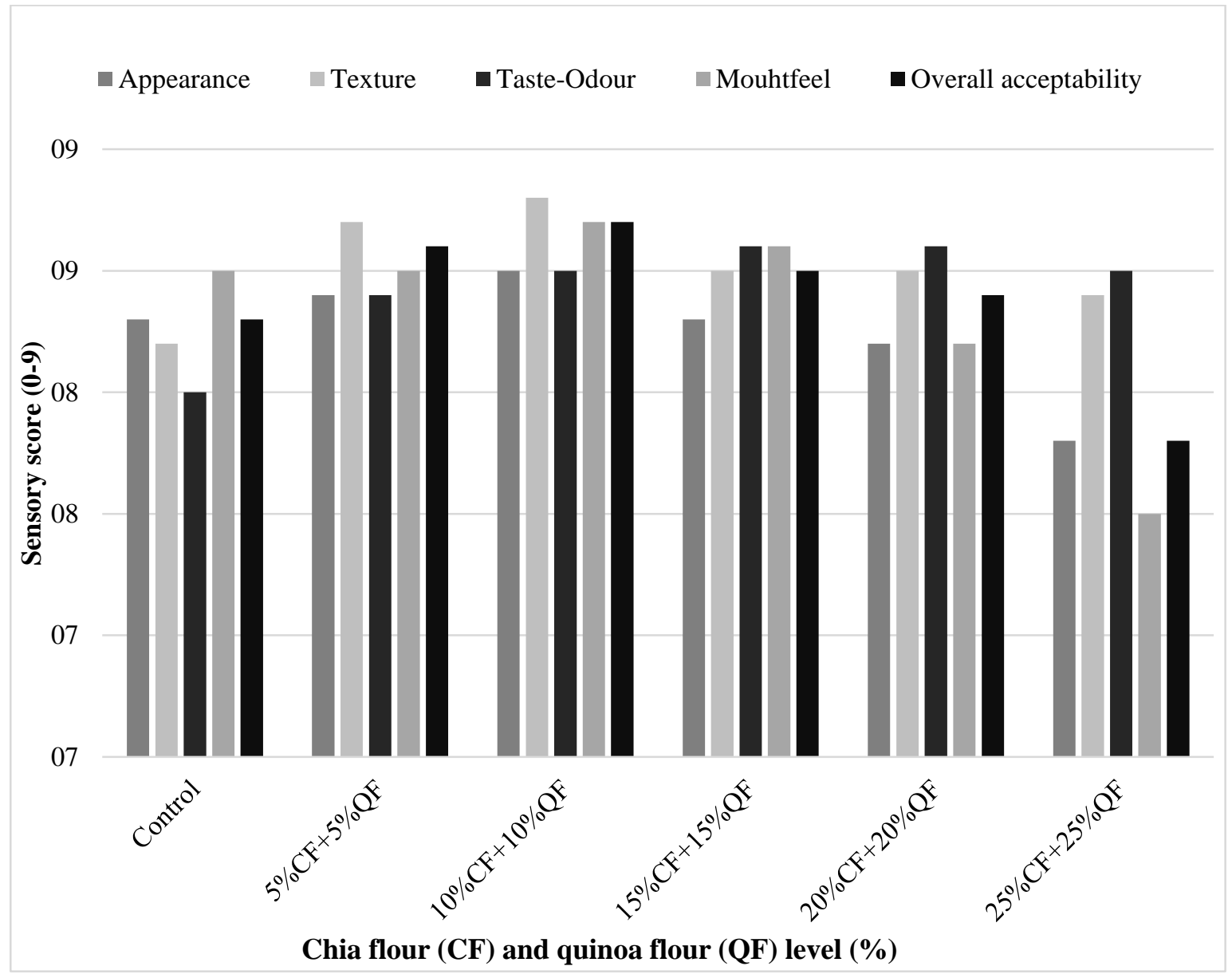

Figure 1. Sensory properties of gluten-free cake samples

\section{CONCLUSION}

$\mathrm{CF}$ and QF were successfully incorporated in gluten-free cake formulation. The usage of $\mathrm{CF}$ and $\mathrm{QF}$ increased the ash, protein, fat, TPC, antioxidant capacity, $\mathrm{Ca}, \mathrm{P}, \mathrm{K}, \mathrm{Mg}, \mathrm{Fe}$ and $\mathrm{Zn}$ contents of gluten free cakes. As the CF and QF levels increased, the PA content of gluten-free cakes increased significantly $(P<0.05)$. All the gluten-free cakes containing $\mathrm{CF}$ and $\mathrm{QF}$ had higher volume index values than control. Glutenfree cakes containing CF and QF up to $20 \%$ and $20 \%$ level were appreciated by the panellists in terms of texture, taste-odour and overall acceptability. 


\section{REFERENCES}

AACC (1990). Approved methods of the American Association of Cereal Chemists. 8th ed. St Paul, U.S.A.

Alencar, N.M.M., Steel, C.J., Alvim, I.D., de Morais, E.C. and Bolini, H.M.A. (2015). Addition of quinoa and amaranth flour in gluten-free breads: Temporal profile and instrumental analysis. LWT-Food Sci Technol, 62: 1011-1018.

Alvarez-Jubete, L., Wijngaard, H., Arendt, E.K. and Gallagher, E. (2010). Polyphenol composition and in vitro antioxidant activity of amaranth, quinoa buckwheat and wheat as affected by sprouting and baking. Food Chem, 119: 770-778.

Barrientos, V.A., Aguirre, A. and Borneo, R. (2012). Chia (Salvia hispanica) can be used to manufacture sugar-snap cookies with an improved nutritional value. Int J Food Stud,1: 135143.

Bath, D.E., Shelke, K. and Hoseney, R.C. (1992). Fat replacers in high ratio cake layer cakes. Cereal Foods World, 37: 495-500.

Bilgiçli, N. and İbanoğlu, Ş. (2015). Effect of pseudo cereal flours on some physical, chemical and sensory properties of bread. J Food Sci Technol, 52: 7525-7529.

Borneo, R., Aguirre, A. and León, A.E. (2010). Chia (Salvia hispanica L) gel can be used as egg or oil replacer in cake formulations. I Am Diet Assoc, 110: 946-949.

Bubert, H. and Hagenah, W.D. (1987). Detection and measurement. In "Inductively coupled plasma emission spectroscopy", Boumans PWJM (ed.), Wiley, New York, 536 -567.

Caruso, R., Pallone, F., Stasi, E., Romeo, S. and Monteleone, G. (2013). Appropriate nutrient supplementation in celiac disease. Ann Med, 45: 522-531.

Coates, W. and Ayerza, R. (1996). Production potential of chia in northwestern Argentina. Ind Crops and Prod, 5: 229-233.

Costantini, L., Lukšič, L,. Molinari, R., Kreft, I., Bonafaccia, G., Manzi, L. and Merendino, N.
(2014). Development of gluten-free bread using tartary buckwheat and chia flour rich in flavonoids and omega-3 fatty acids as ingredients. Food Chem, 165: 232-240.

Coulter, L. and Lorenz, K. (1990). Quinoacomposition, nutritional value, food applications. Lebensm-Wiss Technol, 23: 203-207.

Demir, M.K. (2014). Use of quinoa flour in the production of gluten-free tarhana. Food Sci Technol Res, 20: 1087-1092.

Demirci, M. (2011). Beslenme (Nutrition), Onur Graphic Publishing House, Tekirdağ, Turkey, ISBN: 975-97146-4-2.

Febles, C.I., Arias, A., Hardisson, A., RodrıguezAlvarez, C. and Sierra, A. (2002). Phytic acid level in wheat flours. J Cereal Sci, 36(1): 19-23.

Francis, F.J. (1998). Colour analysis. In "Food Analysis" S.S. Nielsen (ed.), Aspen Publishers, New York.

Giménez, M.A., Drago, S.R., Bassett, M.N., Lobo, M.O. and Sammán., N.C. (2016). Nutritional improvement of corn pasta-like product with broad bean (Vicia faba) and quinoa (Chenopodium quinoa). Food Chem, 199: 150-156.

Gohara, A.K., Souza, A.H., Rodrigues, Â.C., Stroher, G.L., Gomes, S. and Souza, N.E. (2013). Chemometric methods applied to the mineral content increase in chocolate cakes containing chia and azuki. J Braz Chem Soc, 24, 771-776.

Gómez, M., Oliete, B., Rosell, C.M., Pando, V. and Fernandez, E. (2008). Studies on cake quality made of wheat-chickpea flour blends. LWT-Food Sci Technol, 41: 1701-1709.

Graf, E. and Eaton, J.W. (1993). Suppression of colonic cancer by dietary phytic acid. Nutr Cancer, 19(1): 11-19.

Green, P.H., Rostami, K. and Marsh, M.N. (2005). Diagnosis of coeliac disease. Best Pract Res Clin Gastroenterol, 19: 389-400.

Haug, W. and Lantzsch, H.J. (1983). Sensitive method for rapid determination of phytate in cereals and cereals products. J Sci Food Agric, 34: 1423-1426. 
Ixtaina, V.Y., Nolasco, S.M. and Tomas, M.C. (2008). Physical properties of chia (Salvia hispanica L.) seeds. Ind Crops Prod, 28: 286-293.

Jancurová, M., Minarovicová, L. and Dandar, A. (2009). Quinoa-a review. Czech J Food Sci, 27: 7179 .

Kozioł, M. (1992). Chemical composition and nutritional evaluation of Quinoa (Chenopodium quinoa Willd). J Food Compos Anal, 5: 35-68.

Kumar, V., Sinha, A.K., Makkar, H.P. and Becker, K. (2010). Dietary roles of phytate and phytase in human nutrition: A review. Food Chem, 120(4): 945-959.

Levent, H. (2017). Effect of partial substitution of gluten-free flour mixtures with chia (Salvia hispanica L.) flour on quality of gluten-free noodles. J Food Sci Technol, 54(7): 1971-1978.

Lorenz, K., Coulter, L. and Johnson, D. (1995). Functional and sensory characteristics of quinoa in foods. Dev Food Sci, 37: 1031-1041.

Marti, A. and Pagani, M.A. (2013). What can play the role of gluten in gluten-free pasta? Trends Food Sci Technol, 31: 63-71.

Muñoz, L.A., Cobos, A., Diaz, O. and Aguilera, J.M. (2013). Chia seed (Salvia hispanica): an ancient grain and a new functional food. Food Rev Int, 29: 394-408.

Murray, J.A., Van Dyke, C., Plevak, M.F., Dierkhising, R.A., Zinsmeister, A.R. and Melton, L.J. 2003. Trends in the identification and clinical features of celiac disease in a North American community. Clin Gastroenterol Hepatol, 1: 19-27.

Norlaily, M.A., Yeap, S.K., Ho, W.Y., Beh, B.K., Tan, S.W. and Tan, S.G. (2012). The promising future of chia, Salvia hispanica L. J Biomed Biotechnol, 2012: 1-9.

Nowak, V., Du, J. and Charrondière, U.R. 2016. Assessment of the nutritional composition of quinoa (Chenopodium quinoa Willd.). Food Chem, 193: 47-54.

Oatway, L., Vasanthan, T. and Helm, J.H. (2001). Phytic acid. Food Rev Int, 17(4): 419-431.
Pagano, A.E. (2006). Whole grains and the glutenfree diet. Pract Gastroenterol, 30: 66.

Pizarro, P.L., Almeida, E.L., Sammán, N.C. and Chang, Y.K. (2013). Evaluation of whole chia (Salvia hispanica L.) flour and hydrogenated vegetable fat in pound cake. LWT- Food Sci Tecbnol, 54: 73-79.

Ranhotra, G.S., Gelroth, J.A., Glaser, B.K., Lorenz, K.J. and Johnson, D.L. (1993). Composition and protein nutritional quality of quinoa. Cereal Chem, 70: 303-305.

Repo-Carrasco-Valencia, R.A.M. and Serna, L.A. (2011). Quinoa (Chenopodium quinoa, Willd.) as a source of dietary fiber and other functional components. Food Sci Technol, 31: 225-230.

Rickard, S.E. and Thompson, L.U. (1997). Interactions and biological effects of phytic acid. In: Antinutrients and phytochemicals in food, Shahidi, F. (ed.), Volume 662, American Chemical Society, pp. 294-312.

Ruales, J. and Nair, B.M. (1993). Content of fat, vitamins and minerals in quinoa (Chenopodium quinoa, Willd) seeds. Food Chem, 48: 131-136.

Saturni, L., Ferretti, G. and Bacchetti, T. (2010). The gluten-free diet: safety and nutritional quality. Nutrients 2: 16-34.

Simopoulos, A.P. (2002). Omega-3 fatty acids in inflammation and autoimmune diseases. J Am Coll Nutr, 21: 495-505.

Steffolani, E., Hera, E., Pérez, G. and Gómez, M. (2014). Effect of chia (Salvia hispanica L) addition on the quality of gluten-free bread. J Food Qual, 37: 309-317.

Taga, M.S., Miller, E.E. and Pratt, D.E. (1984). Chia seeds as a source of natural lipid antioxidants. J Am Oil Chem Soc, 61: 928-931.

Thompson, L.U. (1993). Potential health benefits and problems associated with antinutrients in foods. Food Res Int, 26(2): 131-149.

Turkut, G.M., Cakmak, H., Kumcuoglu, S. and Tavman, S. (2016). Effect of quinoa flour on gluten-free bread batter rheology and bread quality. J Cereal Sci, 69: 174-181. 
Vázquez-Ovando, A., Rosado-Rubio, G., ChelGuerrero, L. and Betancur-Ancona, D. (2009). Physicochemical properties of fibrous fraction from chia (Salvia hispanica L.). LWT-Food Sci Technol, 42:168-173.

Vega-Gálvez, A., Miranda, M., Vergara, J., Uribe, E., Puente, L. and Martínez, E.A. (2010). Nutrition facts and functional potential of quinoa (Chenopodium quinoa willd.), an ancient Andean grain: a review. J Sci Food Agric, 90: 2541-2547.
Wronkowska, M., Zielińska, D., Szawara-Nowak, D., Troszyńska, A. and Soral-Śmietana, M. (2010). Antioxidative and reducing capacity, macroelements content and sensorial properties of buckwheat-enhanced gluten-free bread. Int J Food Sci Technol, 45: 1993-2000.

Zhou, J.R. and Erdman Jr, J.W. (1995). Phytic acid in health and disease. Crit Rev Food Sci Nutr, 35(6): 495-508. 